\title{
Distribution of inorganic phosphorus in profiles and particle fractions of Anthrosols across an established riparian buffer and adjacent cropped area at the Dian lake (China)
}

\author{
Guo Sheng Zhang and Jian Cha Li \\ Environmental Science and Ecological Rehabilitation Institute of Yunnan University, Kunming 650091, China \\ Correspondence to: Guo Sheng Zhang (gshzhang@ynu.edu.cn)
}

Received: 26 September 2015 - Published in Solid Earth Discuss.: 12 November 2015

Revised: 4 February 2016 - Accepted: 5 February 2016 - Published: 19 February 2016

\begin{abstract}
Riparian buffers can trap sediment and nutrients sourced from upper cropland, minimizing the eutrophication risk of water quality. This study aimed to investigate the distributions of soil inorganic phosphorus (Pi) forms among profile and particle-size fractions in an established riparian buffer and adjacent cropped area at the Dian lake, southwestern China. The Ca-bound fraction (62\%) was the major proportion of the Pi in the riparian soils. After 3 years' restoration, buffer rehabilitation from cropped area had a limited impact on total phosphorus (TP) concentrations, but has contributed to a change in Pi forms. In the $0-20 \mathrm{~cm}$ soil layer, levels of the Olsen-P, non-occluded, Ca-bound, and total Pi were lower in the buffer than the cropped area; however, the Pi distribution between the cropped area and the buffer did not differ significantly as depth increased. The clay fraction corresponded to $57 \%$ of TP and seemed to be both a sink for highly recalcitrant $\mathrm{Pi}$ and a source for labile $\mathrm{Pi}$. The lower concentration of $\mathrm{Pi}$ forms in the silt and sand particle fraction in the surface soil was observed in the buffer area, which indicated that the Pi distribution in coarse particle fraction had sensitively responded to land use changes.
\end{abstract}

\section{Introduction}

Eutrophication of surface water has been linked to the runoff of excess nutrients from agricultural soils in many parts of the world. The improper management or use of phosphorus (P) fertilizer during cultivation enhances the P transport, affecting the water quality and leading to alterations in water ecosystems (Sharpley et al., 2003; Troitiño et al., 2008). Ri- parian buffers are an efficient and economical tool to reduce agricultural non-point source pollution (Correll, 2000; Novara et al., 2013). Because of the filtering function of soil, the effectiveness of riparian buffers in reducing sediment and nutrient loading in surface and subsurface flows from cropland has been shown across many geographic regions (Dosskey et al., 2010; Keesstra et al., 2012).

Soil erosion and loss of soil nutrients have been serious environmental problems in China (Q. Y. Li et al., 2014; X. H. Li et al., 2014). Much experimental evidence from research on both arable and buffer soils indicates that $\mathrm{P}$ is transported from soil to water with eroded soil (Abrams and Jarrell, 1995; Villa et al., 2014). Minimizing the risk of P enrichment of surface water bodies with $\mathrm{P}$ transported from soils will require specific attention to the forms of $\mathrm{P}$ in soils. Phosphorus distribution in chemical fractions can vary among land uses, which can be a useful indicator for assessing the potential stability of P in soils (Sheklabadi et al., 2014). Soil inorganic $\mathrm{P}(\mathrm{Pi})$ has been considered as a greater risk for eutrophication of surface water than the organic forms of P (Mooer and Reddy, 1994; Kang et al., 2011). The conversion of cropped soils to buffer strip can alter P stability. Roberts et al. (2012) found that the buffer strip soils are enriched in soluble P compared with adjacent agricultural land. Schroeder and Kovar (2006) reported that levels of the iron (Fe)-P fractions were higher in the buffer area than crop field over a 20-year period.

Soil texture is an essential factor dominating soil $\mathrm{P}$ dynamics. Tiessen et al. (1983) reported the $\mathrm{NaOH}$-extractable $\mathrm{Pi}$ forms were concentrated in the finer particle-size fractions $(<2 \mu \mathrm{m})$, and sulfuric acid extractable $\mathrm{P}$ accumulated, particularly in the coarse silt $(5-50 \mu \mathrm{m})$ fraction. Makarov et al. (2004) found the greatest proportions of soil total $\mathrm{P}$ 
and organic $\mathrm{P}$ in A horizons were concentrated in the 5$50 \mu \mathrm{m}$ fraction at the northwestern Caucasus. Neufeldt et al. (2000) reported that $P$ tended to accumulate as recalcitrant $P$ forms in the clayey soils in central Brazil. Management practices can affect the $\mathrm{P}$ compounds present in arable soils and their stability; therefore, the distribution of soil Pi can be influenced by land uses. Little information exists, however, on the effects of land uses on the distribution of Pi within soil particle-size classes. The distribution of the different $\mathrm{Pi}$ forms associated with soil particles would be useful knowledge for understanding Pi dynamics in soils for sustainable $\mathrm{P}$ management and for the assessment of the risk of $\mathrm{P}$ losses.

In the basin of the Dian lake, southwestern China, agriculture development from conventional field crops to intensive horticultural crops has occurred for more than 20 years. Due to severe eutrophication of the Dian lake, a conservation program of Dian lake was established in 2009. Since its inception, thousands of hectares of buffers have been established by converting strips of cropland around the lake riparian zones to permanent vegetation. It is critical to know how the change of land use affects soil $\mathrm{P}$ and its various forms, which in turn affect its potential as a pollutant.

In the present study we applied the Kuo fractionation (Kuo, 1996) to whole soil samples and particle-size fractions of different land uses. The objective of this study was to identify the transformations of the inorganic $\mathrm{P}$ forms in the plateau lake riparian buffer after land use changes from cropped area to vegetation buffer.

\section{Materials and methods}

\subsection{Site description}

The study area is located on the southeastern basin of the Dian lake in the mid-Yunnan Plateau $\left(24^{\circ} 42^{\prime}-46^{\prime} \mathrm{N}\right.$, $102^{\circ} 41^{\prime}-43^{\prime} \mathrm{E}$ ), China, which is the last large agricultural production area in the basin of the Dian lake. This semihumid region within the subtropical climatic zone is characterized by a dry winter and a moist summer. Mean annual air temperature in the area is $14.7^{\circ} \mathrm{C}$ and mean annual rainfall is $953 \mathrm{~mm}$, of which $80 \%$ falls between June and October. The soil at the site is a paddy soil (Soil Taxonomy: Anthrosols, according to IUSS Working Group WRB, 2014). The cropped area has been in vegetable cropping (4-6 harvests per year) in a plastic greenhouse for more than 20 years. After each harvest in a year, the field is rotary plowed to a $0.15 \mathrm{~m}$ depth. A large amount of chemical fertilizer and animal manure is applied in this production area, resulting in $\mathrm{P}$ application of approximately $136-195 \mathrm{~kg} \mathrm{ha}^{-1}$ each year (Wang et al., 2015). The buffer area, which is approximately 100-200 $\mathrm{m}$ wide, was converted from the cropped area in 2009 into an indigenous tree plantation (Salix babylonica $L$. and Metasequoia glyptostroboides). The tree density of Salix

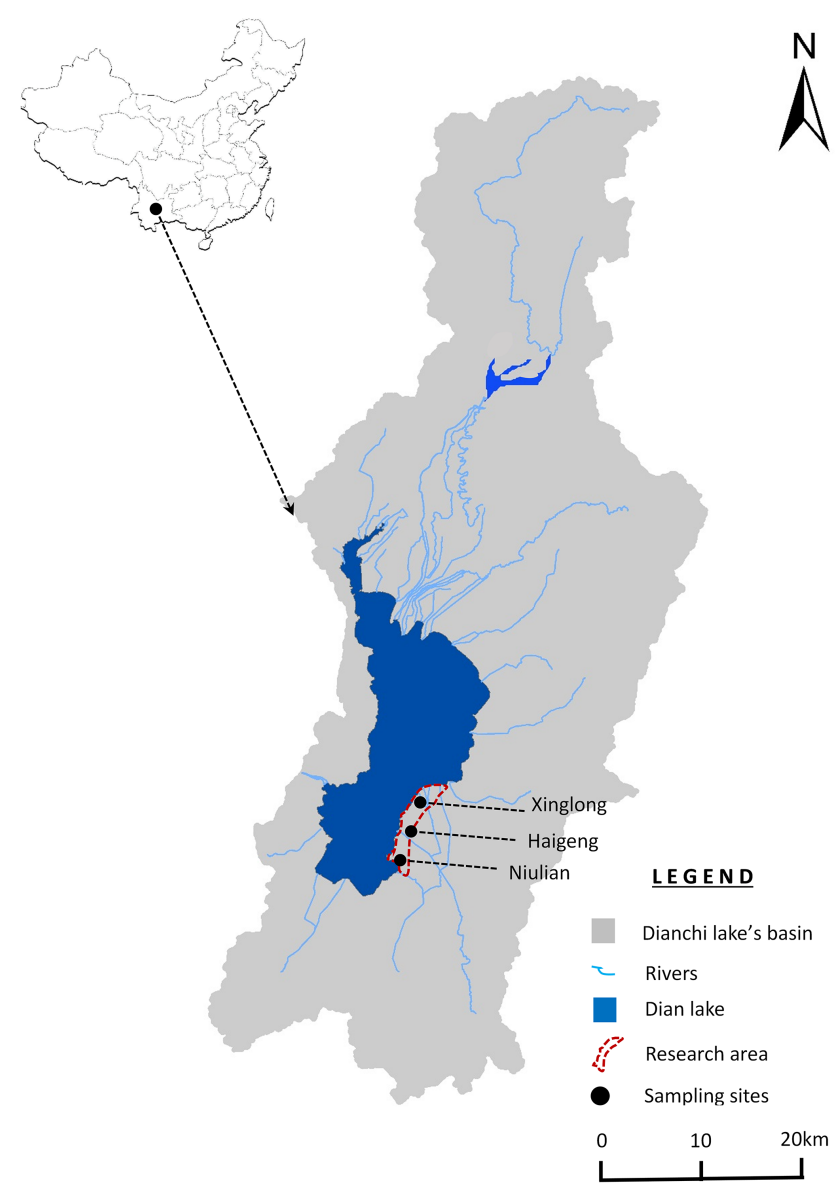

Figure 1. Map of the research area with sampling sites.

babylonica L. and Metasequoia glyptostroboides is 180 and 261 trees ha $^{-1}$ in the buffer area, respectively.

\subsection{Soil sampling}

All the soils in this study were collected in the Niulian (NL, $24^{\circ} 42^{\prime} 30^{\prime \prime} \mathrm{N}, 102^{\circ} 41^{\prime} 06^{\prime \prime} \mathrm{E} ; 1889 \mathrm{~m}$ above sea level), Haigeng ( $\mathrm{HG}, 24^{\circ} 44^{\prime} 22^{\prime \prime} \mathrm{N}, 102^{\circ} 41^{\prime} 48^{\prime \prime} \mathrm{E} ; 1891 \mathrm{~m}$ above sea level), and Xinglong (XL, $24^{\circ} 46^{\prime} 09^{\prime \prime} \mathrm{N}, 102^{\circ} 43^{\prime} 40^{\prime \prime} \mathrm{E}$; $1892 \mathrm{~m}$ above sea level) sites which are located at the southern part of the basin of the Dian lake in 2012 (Fig. 1). In the drought season (from November to next May), the shallow ground water levels were about $0.3,0.7$, and $1.2 \mathrm{~m}$ deep in the buffer at NL, HG, and XL, whereas the shallow ground water levels were about $0.1,0.4$, and $1.0 \mathrm{~m}$ deep at NL, HG, and $\mathrm{XL}$ in the rainy season (from June to October), respectively. Because of drainage, the shallow ground water levels were below $1 \mathrm{~m}$ deep in the cropped area both at NL and HG. Soil cores were collected during April and May of 2012 to a depth of $100 \mathrm{~cm}$ at $20 \mathrm{~cm}$ intervals by a soil borer. At each site, five cores were collected from randomly selected locations across a $50 \mathrm{~m} \times 50 \mathrm{~m}$ area of both the buffer and the cropped area with a soil drill. There were 15 core samples 
of soil profiles for buffer and cropped area respectively. All soil samples were air-dried, passed through a $2 \mathrm{~mm}$ sieve, and stored at $20^{\circ} \mathrm{C}$.

\subsection{Laboratory analyses}

Soil subsamples were ground with a pestle and mortar prior to total soil nutrient analysis. Subsamples were analyzed for $\mathrm{pH}$ ( soil : water $=1: 2.5$ ); soil organic carbon and total nitrogen were determined by the oil-bath potassium dichromate $\left(\mathrm{K}_{2} \mathrm{Cr}_{2} \mathrm{O}_{7}\right)$ titration method and the macro-Kjeldahl method (Shi, 1998). Particle size distribution of soil was determined by the hydrometer method (Gee and Bauder, 1986). Particle density of soil $\left(\mathrm{Mg} \mathrm{m}^{-3}\right)$ was measured using the liquid pycnometer method, with distilled water as the displacing liquid (Blake and Hartge, 1986). All the measurements of each sample were triplicated.

The particle-size fractionation followed a fractionation procedure of Christensen (1992) and Neufeldt et al. (2000). $50 \mathrm{~g}$ of soil in $100 \mathrm{~mL}$ deionized water was intensely shaken for $3 \mathrm{~h}$ to disaggregate the coarse-sand fraction. The coarse sand $(>250 \mu \mathrm{m})$ was obtained by passing the suspension through a $250 \mu \mathrm{m}$ sieve, and dried at $40^{\circ} \mathrm{C}$. The remaining suspension was exposed to $1500 \mathrm{~J} \mathrm{~mL}^{-1}$ ultrasonic energy using a probe-type disintegrator. The clay fraction $(<2 \mu \mathrm{m})$ was freeze-dried after separating it from the fine sand and the silt by repeated centrifugation until the supernatant was clear. The fine sand $(250-50 \mu \mathrm{m})$ was obtained by passing through a $50 \mu \mathrm{m}$ sieve, and dried at $40^{\circ} \mathrm{C}$, whereas the remaining silt $(2-50 \mu \mathrm{m})$ in the remaining suspension was freeze-dried. Due to the low recovery of sand fractions, it was necessary to combine coarse-sand and fine-sand fractions to give one sample for chemical analyses.

Total soil $\mathrm{P}$ was determined using wet oxidation (Shi, 1998). Olsen $\mathrm{P}$ was determined by adding $20 \mathrm{~mL}$ of $0.5 \mathrm{M} \mathrm{NaHCO}, \mathrm{pH} 8.5$ extractant to $1.00 \mathrm{~g}$ of soil, shaking for $30 \mathrm{~min}$, and filtering through Whatman ${ }^{\circledR} 42$ filter paper (Kuo, 1996). Inorganic $P$ fractions were conducted by Kuo fractionation schemes (Zhang and Kovar, 2000). A $0.5 \mathrm{~g}$ soil sample was placed in a $50 \mathrm{~mL}$ centrifuge tube and sequentially extracted with $25 \mathrm{~mL}$ each of $1.0 \mathrm{M} \mathrm{NH}_{4} \mathrm{Cl}, 0.5 \mathrm{M} \mathrm{NH} 4 \mathrm{~F}$ (loosely bound $\mathrm{Pi}$ ), and $0.1 \mathrm{M} \mathrm{NaOH}$ (non-occluded $\mathrm{Pi}$ ) in that order. Each extraction was performed for $0.1,1$, and $17 \mathrm{~h}$ using a horizontal shaker followed by centrifugation at $3300 \mathrm{rpm}$ for $15 \mathrm{~min}$, respectively. The occluded Pi was subsequently extracted by adding $20 \mathrm{~mL}$ of $0.3 \mathrm{M} \mathrm{Na}_{3} \mathrm{C}_{6} \mathrm{H}_{5} \mathrm{O}_{7}$, $2.5 \mathrm{~mL}$ of $1 \mathrm{M} \mathrm{NaHCO}_{3}$, and $0.5 \mathrm{~g} \mathrm{Na}_{2} \mathrm{~S}_{2} \mathrm{O}_{4}$ to the residue in each tube and heating for $15 \mathrm{~min}$ at $85^{\circ} \mathrm{C}$, followed by centrifugation at $3300 \mathrm{rpm}$ for $15 \mathrm{~min}$. The calciumbound $\mathrm{Pi}$ was subsequently extracted by adding $25 \mathrm{~mL}$ of $0.25 \mathrm{M} \mathrm{H}_{2} \mathrm{SO}_{4}$ followed by centrifugation at $3300 \mathrm{rpm}$ for $15 \mathrm{~min}$. All the measurements of each sample were triplicated.

\subsection{Statistical analysis}

All data were analyzed by two-way analyses of variance in PASW Statistics 17.0.2 for Windows (SPSS Inc., 2009). The treatment means were compared using Fisher's least significant difference (LSD) test and Duncan's multiple range test. Significant differences were considered at a $P<0.05$.

\section{Results and discussion}

\subsection{Land-use effects on soil physicochemical properties}

Summarized results from particle-size analysis are presented in Fig. 2. The soils in the Xinglong (XL) and Haigeng (HG) sites have less clay than those at the Niulian (NL) sites. Soil textures under the buffer and crop fields were determined as a clay in all soil depths at the NL sites, compared to clay loam at both the XL and HG sites, according to soil texture classification of USDA system. The higher percentages of sand in the buffer upper soils $(0-40 \mathrm{~cm})$ at the NL and HG sites indicated that the buffer has acted as a sink for coarse sediments but not for finer particles.

Soil organic carbon (SOC) and nitrogen (N) concentrations at the NL sites were significantly higher than the HG and XL sites (Fig. 3). This was probably related to the shallower groundwater table and higher clay content of the NL soils. Wiesmeier et al. (2012) and Grüneberg et al. (2013) also observed that the OC stocks were mainly controlled by pedogenetic properties such as clay content and permanent water saturation.

Pedogenetic properties such as clay and iron oxide content probably provide further explanation for the accumulation of SOC in the subsoil. Organic carbon and nitrogen concentrations in the buffer soils $(0-100 \mathrm{~cm}$ at the NL sites and $0-20 \mathrm{~cm}$ at the HG and XL sites) were significantly higher than in the cropped soils (Fig. 3). The greater accumulation of plant debris by the revegetation and the slower rate of organic matter decomposition by the lack of cultivation might have contributed to the build up of soil organic carbon (SOC) in the buffer soils (Reddy et al., 2008). There was a significant relationship between SOC and $\mathrm{N}$ at the research area ( $r=0.944, P<0.01)$. Several studies have indicated that the rate of SOC accumulation is controlled by the rate of $\mathrm{N}$ accumulation in the early stages of vegetation regeneration of abandoned agricultural soils (Knops et al., 2000; Poulton et al., 2003). Differences of SOC and $\mathrm{N}$ between the crop and the buffer soils were less significant as depth increased at the HG and XL sites but increased at the NL sites. The organicrich subsurface soil in the buffer area at the NL sites may been due to the buried river channel sediment or peat.

The higher $\mathrm{pH}$ of surface soil $(0-20 \mathrm{~cm})$ in the cropped area reflects the regular fertilization increasing salt concentration in the soil solution (Godsey et al., 2007). In addition, the $\mathrm{pH}$ of the NL soils was $0.2-0.5$ higher than the $\mathrm{pH}$ of 

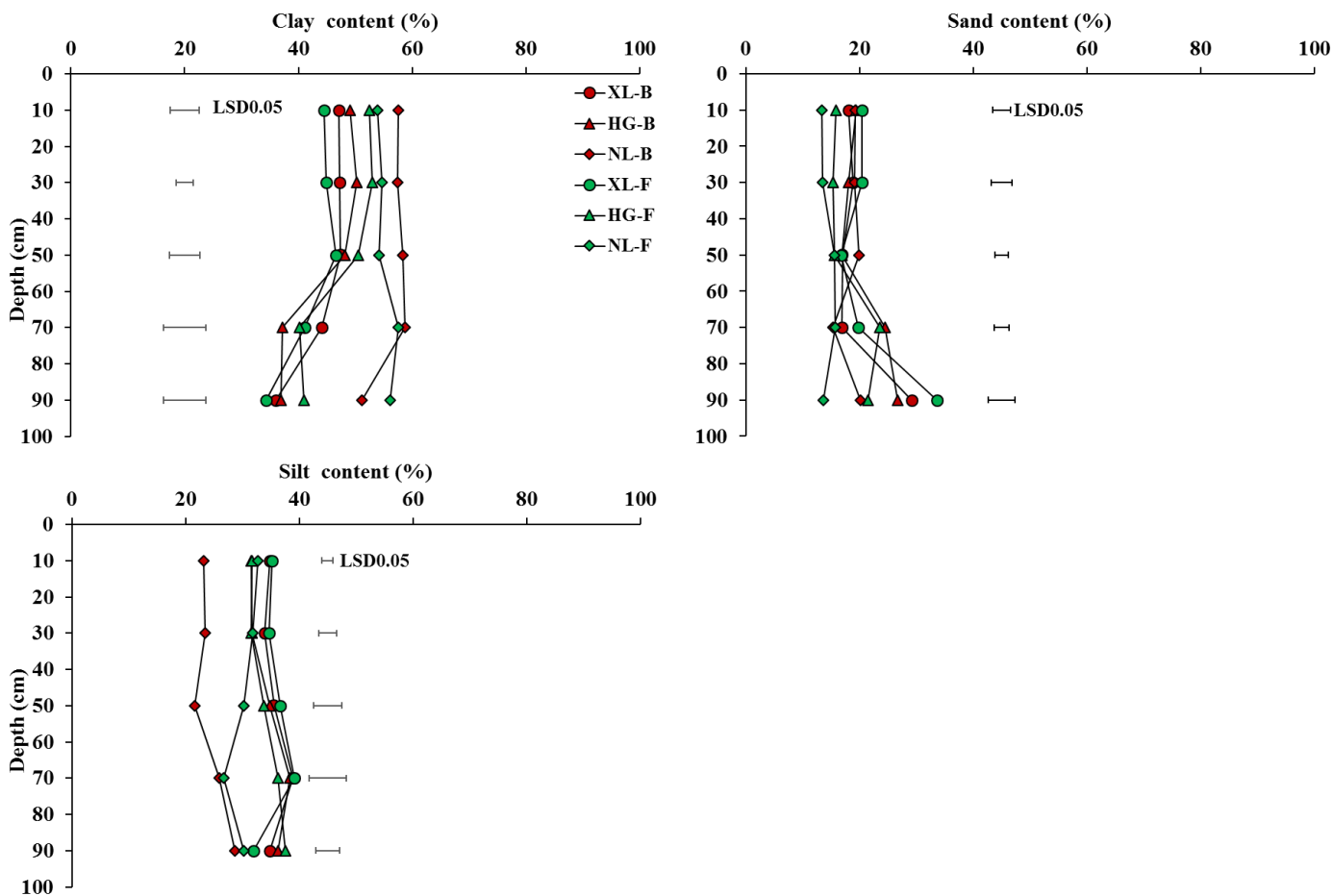

Figure 2. The distribution of soil particle-size fractions in profiles at different land use sites. Buffer of Xinglong site (XL-B); buffer of Haigeng site (HG-B); buffer of Niulian site (NL-B); crop field of Xinglong site (XL-F); crop field of Haigeng site (HG-F); crop field of Niulian site (NL-F).
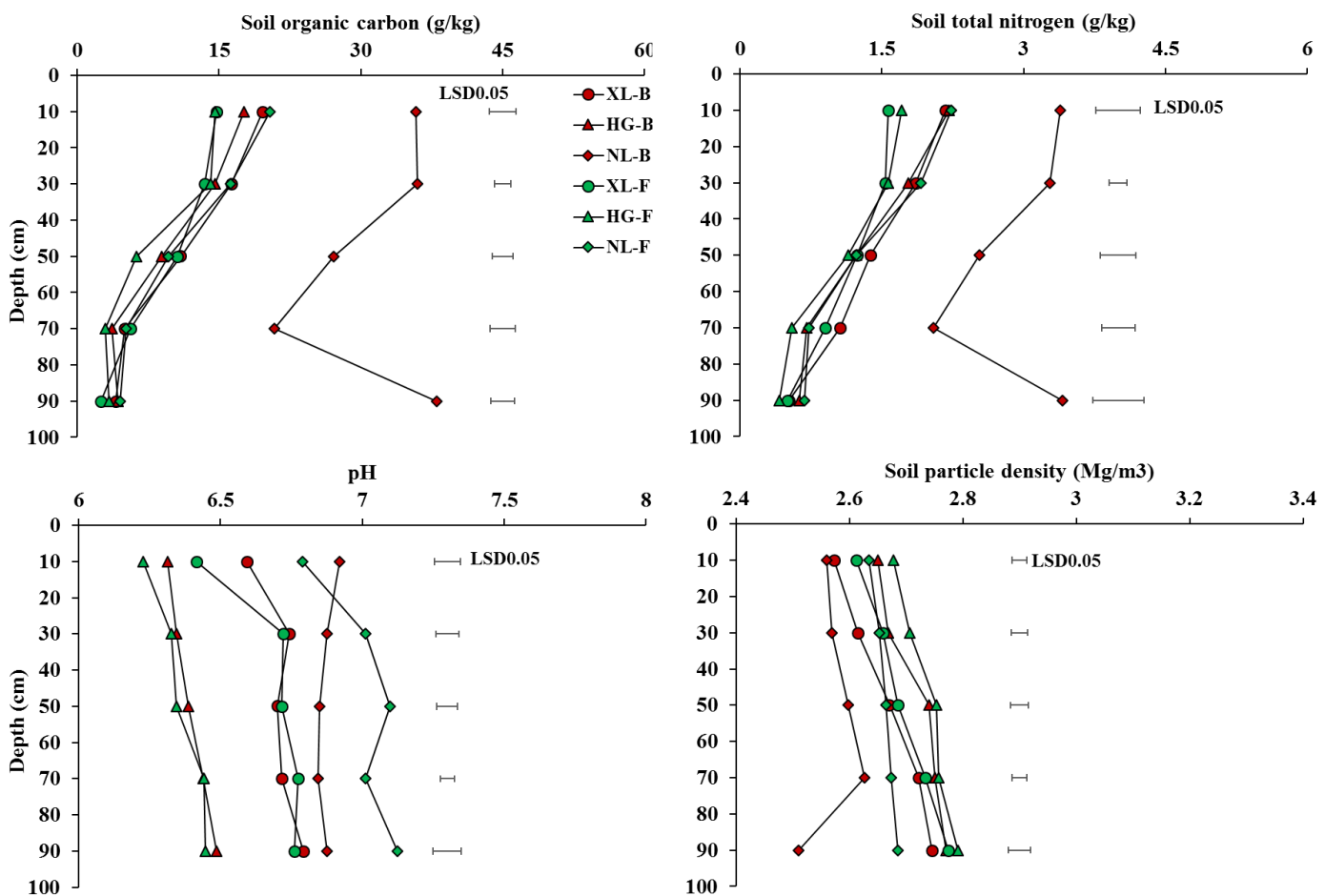

Figure 3. The distribution of soil physicochemical properties in profiles at different land use sites. For abbreviations, see Fig. 2. 

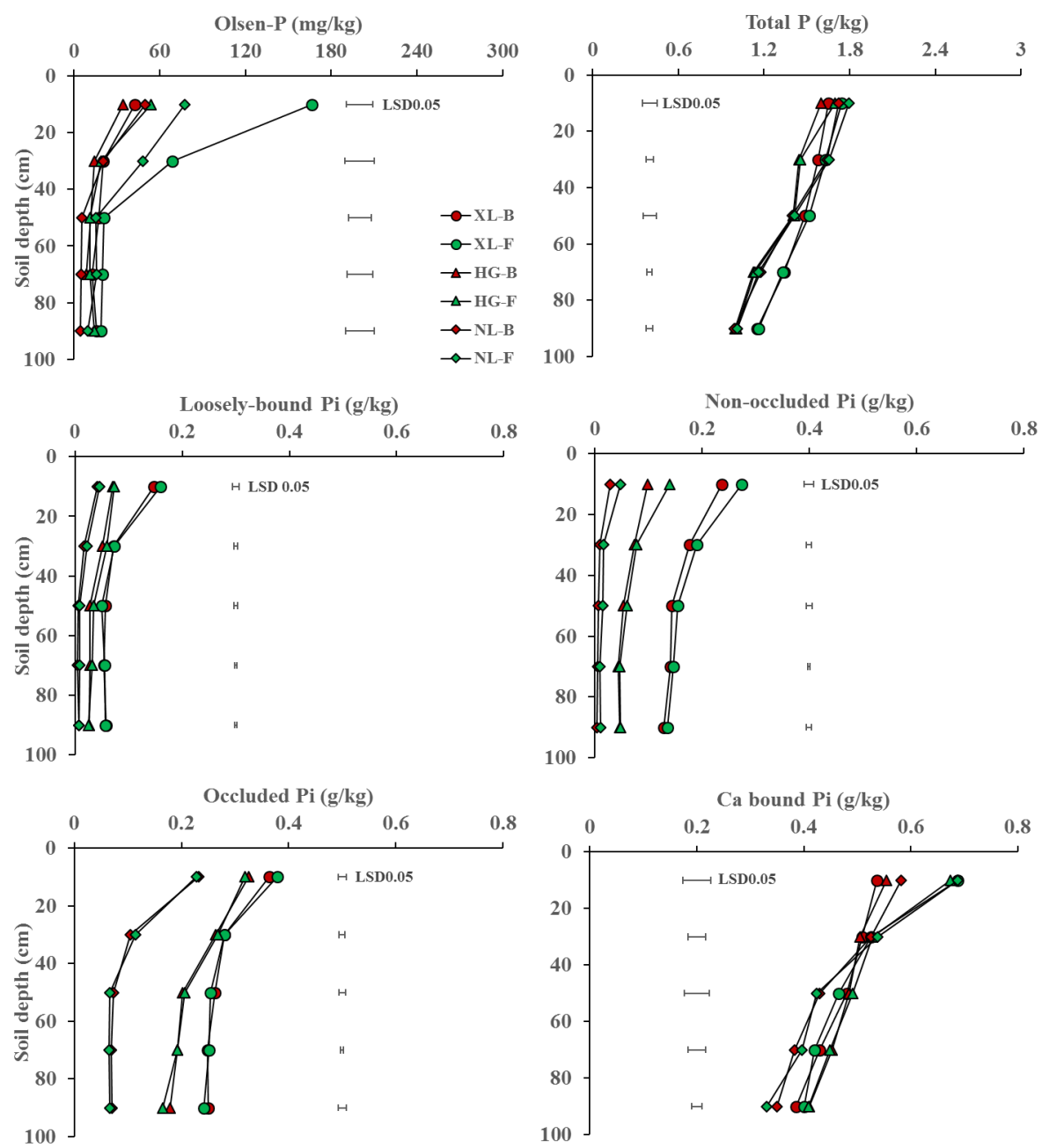

Figure 4. The concentrations of $P$ forms in soil profiles at different land use sites. For abbreviations, see Fig. 2.

the XL and HG soils. Compared to the cropped soils, the lower $\mathrm{pH}$ of subsurface buffer soils in the NL sites may be explained as acid production by plant roots due to excess cation uptake (Tang et al., 2013). Soil particle density $\left(\rho_{\mathrm{d}}\right)$ of the NL sites was significantly lower than that of the XL and HG sites.

\subsection{Land-use effects on $P$ fractions in whole soil samples}

Fertilizer application in cropped area has a significant effect on increasing the available $\mathrm{P}$ forms in the cropped soils (Fig. 4). Comparison of Olsen-P levels in the crop and buffer soils indicated that a higher amount of available $\mathrm{P}$ (99.3 $\mathrm{mg} \mathrm{kg}^{-1}$ ) was accumulated in topsoil $(0-20 \mathrm{~cm})$ in crop areas. Yan et al. (2012) reported that excess $P$ input has led to soil enrichment of Olsen-P up to $100-179 \mathrm{mg} \mathrm{kg}^{-1}$ in the surface soil under the intensive vegetable production systems of China. The higher extractable P in the cropped soil implicated that it would be more easily depleted by movement from the soil surface by erosion and leaching (Sharpley et al., 2003). Also, non-occluded, Ca-bound, and total inorganic $P$ (Pi) levels in the $0-20 \mathrm{~cm}$ layer were higher in the cropped soil than in the buffer soil. This may be due to the regular fertilization in surface soil for crop growth. Ellert and Gregorich (1996) and Negassa et al. (2009) also reported amounts of soil Pi increased with fertilizer application, with non-occluded and Ca-bound Pi constituting the major proportion of the change. Neufeldt et al. (2000) observed that fertilizer $\mathrm{P}$ has also been sorbed in a highly recalcitrant form and suggested that all $\mathrm{P}$ fractions are linked. No significant difference in loosely bound and occluded $\mathrm{Pi}$ and total $\mathrm{P}$ distribution between these crop and buffer soils was observed in this study. However, Crews and Brookes (2014) reported that herbaceous perennials developed labile organic $\mathrm{P}$ pools in place of occluded inorganic $P$, whereas annual agroecosystems developed occluded inorganic $\mathrm{P}$ pools in place of labile organic P.

Furthermore, Olsen-P, Pi fractions, and TP levels were higher in the $0-20 \mathrm{~cm}$ samples compared to other sampling 
Table 1. Percentage of inorganic phosphorus forms on total Pi in the $0-20 \mathrm{~cm}$ soil layer of different sites.

\begin{tabular}{lrrrr}
\hline & \multicolumn{4}{c}{ Percentage of Pi forms on total Pi } \\
\cline { 2 - 5 } & Loosely bound & Non-occluded & Occluded & Ca-bound \\
\hline $\begin{array}{c}\text { Niulian site } \\
\text { Buffer area } \\
\text { Crop area }\end{array}$ & $5(1.1) \mathrm{c}$ & $5(1.4) \mathrm{c}$ & $26(1.1) \mathrm{b}$ & $64(1.8) \mathrm{b}$ \\
\hline $\begin{array}{l}\text { Haigeng site } \\
\text { Buffer area }\end{array}$ & $4(1.8) \mathrm{c}$ & $4(1.7) \mathrm{c}$ & $23(1.3) \mathrm{c}$ & $69(1.5) \mathrm{a}$ \\
$\begin{array}{l}\text { Crop area } \\
\text { Xinglong site }\end{array}$ & $6(1.8) \mathrm{b}$ & $11(2.1) \mathrm{b}$ & $31(1.4) \mathrm{a}$ & $51(1.7) \mathrm{d}$ \\
$\begin{array}{l}\text { Buffer area } \\
\text { Crop area }\end{array}$ & $11(1.5) \mathrm{a}$ & $18(2.4) \mathrm{b}$ & $26(1.3) \mathrm{b}$ & $56(2.0) \mathrm{c}$ \\
\hline $\begin{array}{l}\text { The values in parentheses are the standard error. Data followed by different lower case letters in the } \\
\text { same column indicate that the percentage of Pi forms is significantly different at } P<0.05 \text { according to } \\
\text { the LSD test. }\end{array}$
\end{tabular}

Table 2. Correlations (Pearson's coefficient, $n=30$ ) among the $\mathrm{P}$ forms.

\begin{tabular}{lrrrrrr}
\hline P forms & TP & Loosely bound & Non-occluded & Occluded & Ca-P & Pi \\
\hline Loosely bound & $0.580^{*}$ & & & & & \\
Non-occluded & $0.639^{*}$ & $0.744^{*}$ & & & & \\
Occluded & $0.620^{*}$ & $0.575^{*}$ & $0.511^{*}$ & & & \\
Ca-P & $0.607^{*}$ & $0.481^{*}$ & $0.504^{*}$ & $0.921^{*}$ & & \\
$\mathrm{Pi}$ & $0.694^{*}$ & $0.697^{*}$ & $0.692^{*}$ & $0.945^{*}$ & $0.955^{*}$ & \\
Olsen-P & $0.490^{*}$ & $0.744^{*}$ & $0.549^{*}$ & $0.612^{*}$ & $0.527^{*}$ & $0.659^{*}$ \\
\hline
\end{tabular}

* Correlation is significant at the 0.01 level (two-tailed).

Table 3. Phosphorus forms in particle-size fractions of the riparian soil.

\begin{tabular}{|c|c|c|c|c|c|}
\hline \multirow[t]{2}{*}{$\mathrm{P}$ forms } & \multicolumn{3}{|c|}{ Particle size classes } & \multirow[t]{2}{*}{$\sum(\mathrm{g} / \mathrm{kg})$} & \multirow[t]{2}{*}{ Whole soil $(\mathrm{g} / \mathrm{kg})$} \\
\hline & $<2 \mu \mathrm{m}(\mathrm{g} / \mathrm{kg})$ & $2-50 \mu \mathrm{m}(\mathrm{g} / \mathrm{kg})$ & $50-2000 \mu \mathrm{m}(\mathrm{g} / \mathrm{kg})$ & & \\
\hline Loosely bound & $0.05 \mathrm{~A}(49 \mathrm{a})$ & $0.05 \mathrm{~A}(38 \mathrm{~b})$ & $0.04 \mathrm{~B}(13 \mathrm{c})$ & 0.05 & 0.05 \\
\hline Non-occluded & $0.09 \mathrm{~A}(46 \mathrm{a})$ & $0.11 \mathrm{~A}(44 \mathrm{a})$ & $0.06 \mathrm{~B}(10 \mathrm{~b})$ & 0.09 & 0.09 \\
\hline Occluded & $0.25 \mathrm{~A}(53 \mathrm{a})$ & $0.23 \mathrm{~B}(33 \mathrm{~b})$ & $0.19 \mathrm{C}(14 \mathrm{c})$ & 0.24 & 0.21 \\
\hline Ca-bound & $0.52 \mathrm{~A}(51 \mathrm{a})$ & $0.51 \mathrm{~A}(34 \mathrm{~b})$ & $0.42 \mathrm{~B}(15 \mathrm{c})$ & 0.50 & 0.48 \\
\hline $\mathrm{TPi}$ & $0.91 \mathrm{~A}(51 \mathrm{a})$ & $0.91 \mathrm{~A}(35 \mathrm{~b})$ & $0.71 \mathrm{~B}(14 \mathrm{c})$ & 0.87 & 0.82 \\
\hline $\mathrm{TP}$ & $1.75 \mathrm{~A}(57 \mathrm{a})$ & $1.25 \mathrm{~B}(28 \mathrm{~b})$ & $1.21 \mathrm{~B}(15 \mathrm{c})$ & 1.48 & 1.39 \\
\hline
\end{tabular}

depths in both areas, suggesting that $\mathrm{P}$ was stratified in both areas. Within each sampling site (crop or buffer soil), TP concentrations decreased as sampling depth increased. Loosely bound, non-occluded, occluded, and total Pi were differed significantly in the $0-40 \mathrm{~cm}$ depth but not below the $40 \mathrm{~cm}$ depth in these soils. Additionally, the percentage of loosely bound, non-occluded $\mathrm{Pi}$ also decreased as sampling depth increased except occluded and Ca-bound Pi (Fig. 4).
Distribution of total $\mathrm{Pi}$ in the soils was, on average, $5 \%$ loosely bound, $9 \%$ non-occluded, $24 \%$ occluded, and $62 \%$ Ca-bound. High levels of Ca-P in these soils suggested that at least some of the soil's alluvial parent material probably originated from the limestone bedrock in the area above the catchment of the Dian lake (Schroeder and Kovar, 2006). Except for the occluded $\mathrm{Pi}$ in the $0-20 \mathrm{~cm}$ layer, the percentages of Pi fractions did not differ significantly between the cropped and the buffer soils. Compared with the cropped 
area topsoils $(0-20 \mathrm{~cm})$, the higher percentages of occluded Pi were found in the buffer topsoils (Table 1). In general, this observation suggests the increasing possibility of the occlusion of $\mathrm{P}$ with $\mathrm{Fe} / \mathrm{Al}$ hydrous oxides or formation of insoluble $\mathrm{Al} / \mathrm{Fe}$ phosphates in buffer soils relative to cropped soils.

Although subsoil Ca-P (below 0-20 cm) alone did not differ among those areas, the others $\mathrm{Pi}$ fractions were greater in the XL soils than in the HG and NL soils (Fig. 4). The NL soil had the lowest loosely bound, non-occluded, occluded, and total Pi (Fig. 4). However, TP concentration did not differ significantly among those areas. Soil TP concentration was positively correlated with clay content $(r=0.508, P<0.01)$. There was not a significant relationship between $\mathrm{Pi}$ fractions and clay content. Occluded Pi was negatively correlated with soil $\mathrm{pH}(r=-0.621, P<0.01)$. Furthermore, there were strong correlations among the $\mathrm{P}$ fractions (Table 2).

\subsection{Land-use effects on inorganic phosphorus fractions in particle-size fractions}

Although the error of individual fractions was up to $12 \%$, the sum of all $\mathrm{Pi}$ fractions in the particle-size fractions was similar to Pi in the whole soil (Table 3). In these soils, the proportion of $\mathrm{P}$ forms decreased continuously with increasing particle size of the fractions. The high proportion of $\mathrm{P}$ forms in the clay fraction reflected that the clay fraction not only seemed to be a sink for highly recalcitrant $\mathrm{Pi}$, but also a source for labile Pi forms (Neufeldt et al., 2000; Suñer and Galantini, 2015). The concentrations of Pi forms in the sand fraction were both significantly lower than in the clay and silt fraction, whereas the concentrations of Pi forms did not differ significantly between the clay and silt fraction. The higher concentration of TP in the clay fraction could be attributed to the enrichment of organic phosphorus in the finer particlesize class. Christensen (2001) reported that in arable soils, clay-sized complexes $(<2 \mu \mathrm{m})$ have the largest concentrations of organic matter $(\mathrm{OM})$, silt-sized $(2-20 \mu \mathrm{m})$ particles are less enriched, and sand-sized ( $>20 \mu \mathrm{m})$ particles usually contain little OM.

Figure 5 shows the distribution of surface soil $(0-20 \mathrm{~cm}) \mathrm{Pi}$ fractions in the particle-size fractions under different land use types. Buffer rehabilitation had no effect on the concentration of Pi fractions within clay fraction, but the coarse particle fraction exhibited a decrease in the concentration of loosely bound, non-occluded, occluded (not in the silt fraction), and Ca-bound Pi. Chen et al. (2015) also reported that topsoil nutrients stored in coarse particle fractions were more sensitive than those stored in the fine fraction to soil recovery. However, Suñer et al. (2014) identified that the coarse fraction of the cultivated field had low levels of $\mathrm{Pi}$ as a consequence of the particulate organic matter decomposition and coarse mineral particle weathering. The reduction of $\mathrm{Pi}$ in coarse particle fractions in the buffer soil may be attributed to the assimilation by vegetation, transformation of $\mathrm{Pi}$, leaching, and erosion (Roberts et al., 2012), which could have a positive

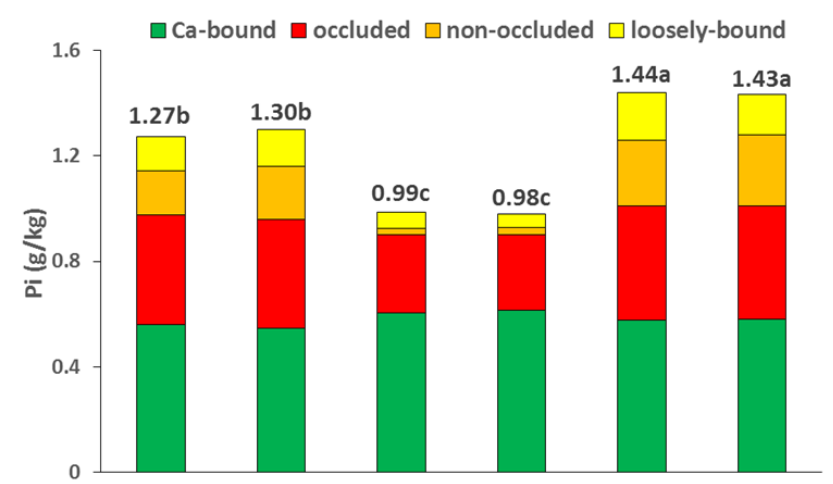

Clay

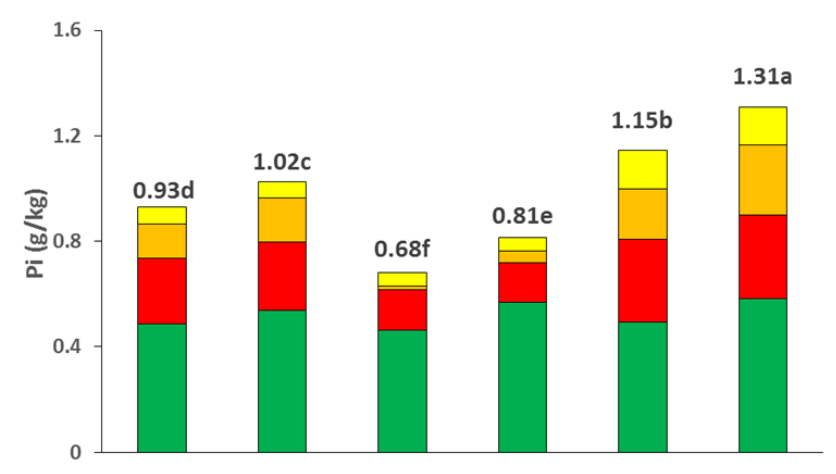

Silt

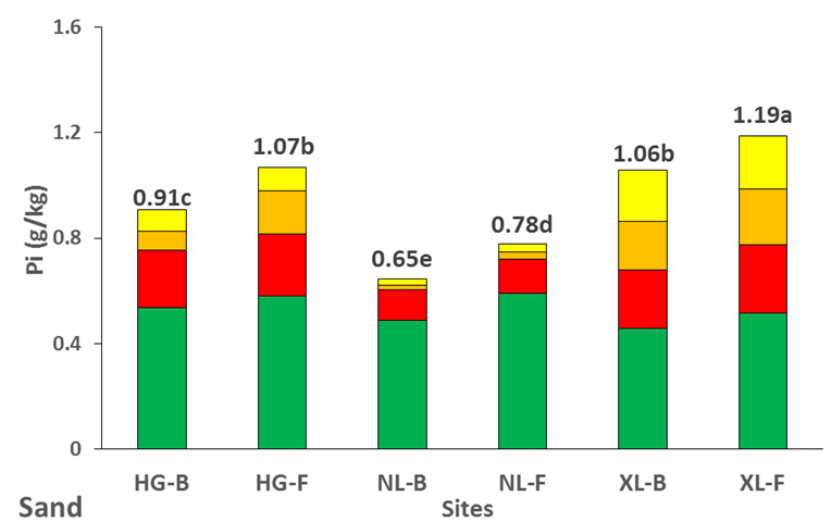

Figure 5. The $\mathrm{P}$ storage in particle-size fractions for Pi fractions of different land use sites. Values above the columns are the sum values of Pi fractions at the same site. Values followed by a similar letter are not significantly different at $P<0.05$ level of significance according to the LSD test. For abbreviations, see Fig. 2.

influence on the function of the buffer to act as a sink for P. In the cropped soil, however, the accumulation of labile $\mathrm{Pi}$ in coarse particle fractions was considered to be more susceptible to lose P via leaching. Zheng et al. (2003) observed that soil particles containing high amounts of extractable $\mathrm{P}$ have a higher $\mathrm{P}$ release potential. The higher non-occluded and occluded $\mathrm{Pi}$ in the sand and silt fractions of the cropped soil indicated that the dissolute fertilizer P was easy trans- 

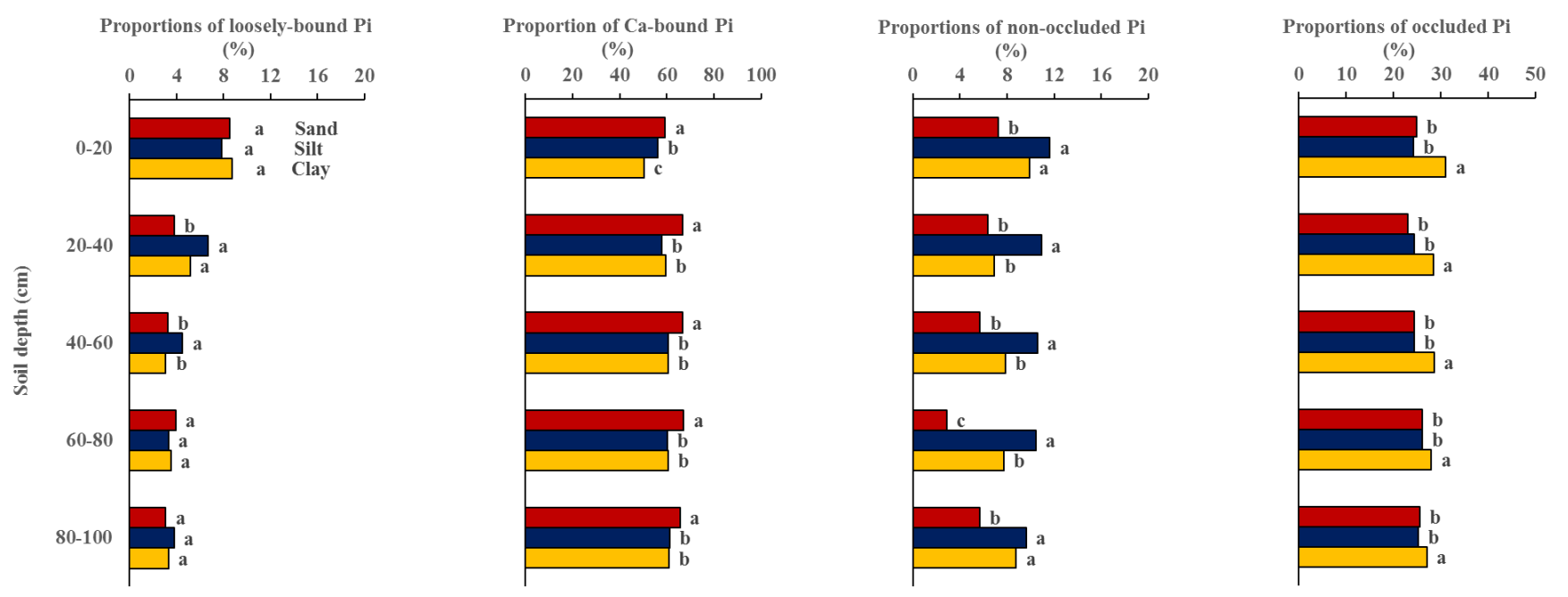

Figure 6. The proportion of Pi forms in particle-size fractions in soil profiles. Values followed by a similar letter in the same layer are not significantly different at $P<0.05$ level of significance according to the LSD test.

formed into more stable Pi forms (Neufeldt et al., 2000). The significant accumulation of Ca-bound $\mathrm{Pi}$ in the sand and silt fractions of the cropped soils as compared to the buffer soils could be explained by the presence of undissolved $P$ fertilizer granules in these fractions, which because of rock phosphate, had been often used together with soluble P fertilizers in these areas. Pätzold et al. (2013) also observed a strongest enrichment of the $\mathrm{HCl}_{\mathrm{dil}}-\mathrm{Pi}$ fraction in soil because of the chemical nature of the basic Thomas slag after 7 decades of fertilizer application. Below $20 \mathrm{~cm}$, the concentrations of $\mathrm{Pi}$ fractions in the particle-size fractions did not differ significantly between the crop and buffer soil.

To enable a better understanding of $\mathrm{P}$ transformations in those riparian soils, regardless of land uses, the average proportions of the $\mathrm{P}$ fractions in the particle-size fractions are presented in Fig. 6. Compared with the sand and silt fractions, the proportions of occluded Pi increased in the clay fraction, which may be related to the increasing adsorption to $\mathrm{Fe} / \mathrm{Al}$ hydrous oxides with finer particle-size classes. Agbenin and Tiessen (1995) and Neufeldt et al. (2000) also reported a similar change of the proportions in Entisols, Inceptisols, and Oxisols from Brazil. The proportions of Ca-bound $\mathrm{Pi}$ in the clay and silt sand fraction were significantly lower than that in the sand fractions, which suggested that the increase in occluded Pi with finer particle-size fractions may be at the expense of Ca-bound Pi. The occluded Pi, which consisted of insoluble $\mathrm{Al} / \mathrm{Fe}$ phosphates, is progressively sequestrated in finer particle-size fractions and therefore more difficult to extract.

The proportion of non-occluded Pi was nearly twice as high in the silt and clay fractions as compared to the sand fractions, which could be attributed to their comparatively higher amounts of discrete Fe/Al hydrous oxides. However, Neufeldt et al. (2000) reported that the proportions of
$\mathrm{NaOH}-\mathrm{Pi}$ showed no consistent trends between the particlesize classes. In contrast, the proportions of loosely bound $\mathrm{Pi}$ did not differ significantly between the particle-size classes, which suggested the potential of labile Pi loss would not decrease with a decrease in the particle-size fractions.

\section{Conclusions}

Inorganic $\mathrm{P}$ forms and their distribution in particle-size fractions were different between the conservation buffer and the continuously cropped area. Amounts of Pi increased in the surface soil of crop field associated with fertilizer P application, with non-occluded and Ca-bound Pi constituting the major proportion of the change. A lower concentration of $\mathrm{Pi}$ forms in the silt and sand particle fraction was found in the surface soil of the buffer, suggesting that $\mathrm{P}$ in these fractions had a lower release potential. The enrichment of labile Pi in the coarse particle fraction of cropped soil implicated that it would be more easily depleted by movement from the soil surface by leaching. More important, the determination of the application of particle-size separation of $\mathrm{P}$ forms can be represented to contribute to a better understanding of soil $\mathrm{P}$ distribution between different land uses.

Acknowledgements. The authors gratefully acknowledge financial support from NSFC (31060085) and National Key Sciences and Technology Program for Water Solutions (2012ZX07102-003).

Edited by: P. Pereira 


\section{References}

Abrams, M. and Jarrell, W. M.: Soil phosphorus as a potential nonpoint source for elevated stream phosphorus levels, J. Environ. Qual., 24, 132-138, 1995.

Agbenin, J. O. and Tiessen, H.: Phosphorus forms in particle-size fractions of a toposequence from northeast Brazil, Soil Sci. Soc. Am. J., 59, 1687-1693, 1995.

Blake, G. R. and Hartge, K. H.: Particle density, In: Methods of Soil Analysis, Part 1, 2nd Edn., edited by: Klute, A., ASA and SSSA, Madison, WI, 377-382 pp., 1986.

Chalmers, A. G., Bacon, E. T. G., and Clarke, J. H.: Changes in soil mineral nitrogen during and after 3 year and 5 year set-aside and nitrate leaching losses after ploughing out the 5 year covers in the UK, Plant Soil, 228, 157-177, 2001.

Chen, X., Duan, Z., and Tan, M.: Restoration Affect Soil Organic Carbon and Nutrients in Different Particle-size Fractions, Land Degrad. Dev., doi:10.1002/ldr.2400, online first, 2015.

Christensen, B. T.: Physical fractionation of soil and structural and functional complexity in organic matter turnover, Eur. J. Soil Sci., 52, 345-353, 2001.

Correll, D. L.: The current status of our knowledge of riparian buffer water quality functions, in: AWRA Proceedings of International Conference on Riparian Ecology and Management in Multi-land Use Watersheds; American Water Resources Association: Middleburg, 28-31 August 2000, Virginia; 5-10, 2000.

Crews, T. E. and Brookes, P. C.: Changes in soil phosphorus forms through time in perennial versus annual agroecosystems, Agric. Ecosys. Environ., 184, 168-181, 2014.

Dosskey, M. G., Vidon, P., Gurwick, N. P., Allan, C. J., Duval, T. P., and Lowrance, R.: The role of riparian vegetation in protecting and improving chemical water quality in streams, J. Am. Water Resour. Assoc., 46, 261-277, 2010.

Ellert, B. H. and Gregorich, E. G.: Storage of carbon, nitrogen and phosphorus in cultivated and adjacent forested soils of Ontario, Soil Sci., 161, 587-603, 1996.

Gee, G. W. and Bauder, J. W.: Particle fraction and particle size analysis, in: Methods of soil analysis, Part 1, 2nd Edn., edited by: Klute, A., ASA and SSSA, Madiso, WI, 383-409, 1986.

Godsey, C. B., Pierzynski, G. M., Mengel, D. B., and Lamond, R. E.: Evaluation of common lime requirement methods, Soil Sci. Soc. Am. J., 71, 843-850, 2007.

Grüneberg, E., Schöning, I., Hessenmöller, D., Schulze, E. D., and Weisser, W. W.: Organic layer and clay content control soil organic carbon stocks in density fractions of differently managed German beech forests, Forest Ecol. Manag., 303, 1-10, 2013.

IUSS Working Group WRB: World Reference Base for Soil Resources 2014: International soil classification system for naming soils and creating legends for soil maps, World Soil Resources Reports No. 106. FAO, Rome, 2014.

Kang, J., Amoozegar, A., Hesterberg, D., and Osmond, D. L.: Phosphorus leaching in a sandy soil as affected by organic and inorganic fertilizer sources, Geoderma, 161, 194-201, 2011.

Keesstra, S. D., Geissen, V., van Schaik, L., Mosse, K., and Piiranen, S.: Soil as a filter for groundwater quality, Curr. Opin. Environ. Sustain., 4, 507-516, 2012.

Knops, J. H. and Tilman, D.: Dynamics of soil nitrogen and carbon accumulation for 61 years after agricultural abandonment, Ecology, 81, 88-98, 2000.
Kuo, S.: Phosphorus, in: Methods of Soil Analysis: Chemical Methods, Part 3, edited by: Sparks, D. L., SSSA, Madison, WI, 869919, 1996.

Li, Q. Y., Fang, H. Y., Sun, L. Y., and Cai, Q. G.: Using the ${ }^{137} \mathrm{Cs}$ technique to study the effect of soil redistribution on soil organic carbon and total nitrogen stocks in an agricultural catchment of Northeast China, Land Degrad. Dev., 25, 350-359, 2014.

Li, X. H., Yang, J., Zhao, C. Y., and Wang, B.: Runoff and sediment from orchard terraces in southeastern China, Land Degrad. Dev., 25, 184-192, 2014.

Makarov, M. I., Haumaier, L., Zech, W., and Malysheva, T. I.: Organic phosphorus compounds in particle-size fractions of mountain soils in the northwestern Caucasus, Geoderma, 118, 101114, 2004.

Moore, P. A. and Reddy, K. R.: Role of eH and pH on phosphorus geochemistry in sediments of Lake Okeechobee, Florida, J. Environ. Qual., 23, 955-964,1994.

Negassa, W. and Leinweber, P.: How does the Hedley sequential phosphorus fractionation reflect impacts of land use and management on soil phosphorus: a review, J. Plant Nutr. Soil Sc., 172, 305-325, 2009.

Neufeldt, H., da Silva, J. E., Ayarza, M. A., and Zech, W.: Landuse effects on phosphorus fractions in Cerrado oxisols, Bio. Fert. Soils, 31, 30-37, 2000.

Novara, A., Gristina, L., Guaitoli, F., Santoro, A., and Cerdà, A.: Managing soil nitrate with cover crops and buffer strips in $\mathrm{Si}$ cilian vineyards, Solid Earth, 4, 255-262, doi:10.5194/se-4-2552013, 2013.

Pätzold, S., Hejcman, M., Barej, J., and Schellberg, J.: Soil phosphorus fractions after seven decades of fertilizer application in the Rengen Grassland Experiment, J. Plant Nutr. Soil Sci., 176, 910-920, 2013.

Poulton, P. R., Pye, E., Hargreaves, P. R., and Jenkinson, D. S.: Accumulation of carbon and nitrogen by old arable land reverting to woodland, Global Change Biol., 9, 942-955, 2003.

Reddy, K. R. and DeLaune, R. D.: Biogeochemistry of Wetlands: Science and Applications, Taylor and Francis Boca Raton, FL, 157-181, 2008.

Roberts, W. M., Stutter, M. I., and Haygarth, P. M.: Phosphorus retention and remobilization in vegetated buffer strips: a review, J. Environ. Qual., 41, 389-399, 2012.

Schroeder, P. D. and Kovar, J. L.: Comparison of Organic and Inorganic Phosphorus Fractions in an Established Buffer and Adjacent Production Field, Commun. Soil Sci. Plan., 37, 1219-1232, 2006.

Sharpley, A. N., Weld, J. L., Beegle, D. B., Kleinman, P. J. A., Gburek, W. J., Moore, P. A., and Mullins, G.: Development of phosphorus indices for nutrient management planning strategies in the United States, J. Soil Water Conserv., 58, 137-152, 2003.

Sheklabadi, M., Mahmoudzadeh, H., Mahboubi, A. A., Gharabaghi, B., and Ahrens, B.: Land use effects on phosphorus sequestration in soil aggregates in western Iran, Environ. Monit. Assess., 186, 6493-6503, 2014.

Shi, R. H.: Soil and Agro-chemical Analysis, 2nd Edn., China Agricultural Press, Beijing, 1998.

SPSS: PASW Statistics 17.0.2 for Windows, Chicago, IL, 2009.

Suñer, L. and Galantini, J. A.: Texture influence on soil phosphorus content and distribution in semiarid pampean grasslands, Int. J. Plant Sci., 7, 109-120, doi:10.9734/IJPSS/2015/16939, 2015. 
Suñer, L., Galantini, J., and Minoldo, G.: Soil Phosphorus Dynamics of Wheat-Based Cropping Systems in the Semiarid Region of Argentina, Appl. Environ, Soil Sci., 2014, 532807, doi:10.1155/2014/532807, 2014.

Tang, C., Weligama, C., and Sale, P.: Subsurface soil acidification in farming systems: its possible causes and management options, in: Molecular Environmental Soil Science, Springer Netherlands, 389-412, 2013.

Tiessen, H., Stewart, J. W. B., and Moir, J. O.: Changes in organic and inorganic phosphorus composition of two grassland soils and their particle size fractions during 60-90 years of cultivation, J. Soil Sci., 34, 815-823, 1983.

Troitiño, F., Gil-Sotres, F., Leirós, M. C., Trasar-Cepeda, C., and Seoane, S.: Effect of land use on some soil properties related to the risk of loss of soil phosphorus, Land Degrad. Dev., 19, 21-35, 2008.

Villa, A., Djodjic, F., and Bergström, L.: Soil dispersion tests combined with topographical information can describe field-scale sediment and phosphorus losses, Soil Use Manage., 30, 342-350, 2014.

Wang, Y., Tanaka, T., Inoue, H., Li, K., Yang, D., and Inamura, T.: Annual nutrient balance and soil chemical properties in heavy multiple cropping system in the coastal area of southeast Lake Dianchi, Yunnan Province, China, Plant Product. Sci., 18, 323335, 2015.
Wiesmeier, M., Spörlein, P., Geuß, U., Hangen, E., Haug, S., Reischl, A., Schilling, B., von Lützow, M., and Kögel-Knabner, I.: Soil organic carbon stocks in southeast Germany (Bavaria) as affected by land use, soil type and sampling depth, Global Change Biol., 18, 2233-2245, 2012.

Yan, Z., Liu, P., Li, Y., Ma, L., Alva, A., Dou, Z., Chen, Q., and Zhang, F. S.: Phosphorus in China's intensive vegetable production systems: Overfertilization, soil enrichment, and environmental implications, J. Environ. Qual., 42, 982-989, 2013.

Zhang, H. and Kovar, J. L.: Phosphorus fractionation, in: Methods of Phosphorus Analysis for Soils, Sediments, Residuals, and Waters, edited by: Pierzynski, G. M., Southern Cooperative Series Bulletin, Kansas State University, Manhattan, Kansas, 396, 5059, 2000.

Zheng, Z., Parent, L. E., and Macleod, J. A.: Influence of soil texture on fertilizer and soil phosphorus transformations in gleysolic soils, Can. J. Soil Sci., 83, 395-403, 2003. 